\title{
SUMMARY
}

\author{
OF TIE: \\ IMPROVEMENTS AND DISCOVERIES
}

Is THF: •

\author{
MEDICAL SCIENCES.
}

\section{ANATOMY AND PIYSIOLOGY.}

1. Structure of the IIuman Placenta.-Johs Dalnrsple, Esq. read before the Medical and Chirurgical Society (Nov. 23, 1841), an interesting paper on tbis subject.

In the early part of the year 1811, Mr. D. states, that hasing pnrsued some aoatomical investigations into the structurc of the human placenta at term, and having made scvcral drawings of the injected capillaries of the tufts, he aflerwards had an opportunity of seeing thc copies of Weber's drawings, given in the "Iconcs Physiologica" of W agncr, and transferred to the pages of Dr. Willis's translation of the latter author's Physiology. The resemblances of the present drawings to thosc giren oy Dr. Willis were so striling, as to go far of. itself to prore the correctncss of both draughtsmen, and to corroborate the views entertained by Weber of the anatomical conditions of the organ. They differed also from the cngravings by Dr. Retd (given in the January nnmber of the "Edinburgh Medical and Surgical Journal" for 1841), inasnucli as nowherc could be seen an artery and rcin running, sidc by side, forming an apparently single ressel, thougli with a double tube, and terminating abruptly, in blunted extremities, where the anastomosis took place between them.

First. It appeared from Mr. D.'s observations that the placenta was made np of the innumerable subdivisions of thc umbilical vesscls terminating in beautifully coiled and convoluted capillaries, which formed tofts or bouquets of vessels, clothed by a prolongation of the cndochorion, derived from the foetal surface of tho organ.

Second. That nowhere did a division of an umbilical artery terminate otherwise than in a branch of the umbilical vein; and each branch as well as tuft of ressels was covered by a prolongation of the before named membrane.

Third. That each tuft was, in fact, a real villus, the endochorion being covered externally with an epithelium-like tissue, having nucleated cells and corpnscles.

Fourth. The uterine surface of the placenta is covered by the decidua, which does not appear to cnter further into the structure of the organ than between tbe lobulcs, and the deptb 20 which it thus penetratcs varies with the depth of the fissures.

Fifth. That fibrous bands stretch from tbe fotal to the placental surface of tbe organ, giving firmness and support to the vessels.

Sixth. That therc are no defined cells in the placenta, but that the nntrient fluids of the mother are poured into the interstices of the tufts, which are not bound or connected together by a common cellular tissue.

Seventh. That on the decidual surface of the placenta are thinly scattered here and there blunt conical papills, about a line and a half in length, made up of innumerable coiled and contorted capillaries. Qnery? Are these the analogues of the fotal cotyledons of the rnminants?

No. VI.-APrL, 1842. 
From these observations, which were giren in minute detail, the author has attempted to simplify the functions of the hnman placenta. He observes, that in the incubated egg, in consequence of the non-connection between the embryo and parent, a nutrient or respiratory organ is indispensablc, and hence the more complicated system of vessels. That in tbe oviparons vertebrata, the vitcllary sac, and the omplialo-mesenteric ressels, represent the placenta of the mammalia, wlich is the absorbent orman of the feetus; but while, in the onc case, the nutrient materials of the mother, already aerated by her lungs, are conveyed by the uterine arteries for absorption and nutrition of the embryo; in tho other, the materials of the blood are absorbed by the folds of the vitelline sac, and conveyed throngh the circulation of the young bird, requiring, however, contact with oxygen for a second circulation. Hence a new membrane, or onc that is persistent up to the time of independent respiration, namely, the allantois; and hence, also, the more complicated system of its ressels. The allantois, as a respiratory membrane, exists only as a rudimentary organ in mammalia; and the function of the placenta being solely that of nutrition by already oxygenized materials, the cord contains only a simplc system of incurrent and cxcurreot vessels.-Prov. Mfed. and Surg. Journ. 18 Dec. 1841.

2. Regeneralion and Union of Nerres.-By MM. Gixtran and Scros. The following observations were made on rabbits, about fifty of which were opcraled on, by sometimes entting across the ischiatic nerves, at other times by remoring a portion varying from two to four lines in length. Thesc physiologists describe the elementary fibres of the nerves as transparent cylinders with double tunics, filled with a fluid resembling liquid albumen. After maceration in water, or after death, this fluid coagnlates and produces the turbid granular aspect which till now, has been considered its natural appenrance. When the two extremities of a nerre which has been cut across become united, the nerre propagates imprcssion through the uniting madium. This is done by means of true primary fibres having been formed through the uniting medium, and the following is the modc in which MM. Gnnther and Schon have observed this to take place. After division of the nerve the two ends retract somewhat, the diameter of the neurilema becomes diminished, and the medullary substance is pushed out in a globular form; exndation of plastic lymph then occurs and fills the wound, and the cut extremities of the nerve become swollen, the upper cxtremity more than the lorrer. This tumefaction of the nerve itself is orving to the presence of plastic iymph effused into the cellular tissuc and also between the neurilema and primitive fibres.

The matter which unites the two end s of the nerve is at first amorphous, hut by degrees primitive fibres shoot through the mass, and becomc visible at the earliest on the eighth week after the division. These ncw fibres are in every respect simi'ar to the original fibres; but the granular exndation and the cellular lissue which surround and envelope them render them difficult of examinatioo. These fibres are not parallel, but exhibit a confused arrangement.

With the regeneration of the fibres of the nerve retnrns tho sensibility and mobillty of the limb or organs to which the nerve was distributed.

But in general the function of the part is not so frce as before the division;the animals not being able to use the limb whose nerve had been divided so freely as the other. The influence of the will over the limb was also observed to be diminished. MMI. Gunther and Schon account for this on the supposition, which is bome out by their experiments, that the numbc: of fibres which arc regenerated is not equal to those which originally existed; besides, it appeared to them that the iegenerated fibres occasionally united the ends of different primitive fibres, so that sensation was not al ways referred to its proper place. They consider that the regeneration or growth of the uniting fibre commenced at tbc superior extremity of the divided nerve, but concede that it is possible that it also may take place from the lower extremity.-Ed. Med. \& Surg. Journ. Jan. 1842, from Archices Générales, March, 1841. 
3. Experimental Researches on the Function of the Skin in MTan and Animols.MI. Decnos, in a very experimcntal paper, shows that a coating of gum-lac put on the skins of animals causes them to die in a longer or shorter timc, by producing convulsirc movements similar to epilepsy. When the animals, coated with gum-lac, were subjected to electricity, they died in a moch shorter time. He next tried the effect of mctallic corerings, as he entertained the notion that, because they had opposite electrical properties, the animals coated with them would die with symptoms of an opposile nature. He therefore cut off the hair from some animals and covcred them with thin plates of tin (tin-foil), and found that they perished with symptoms of debility, the reverse of what he had noticed when the coating consisted of a resinous substance. When the tin was corered with a coating of gum-lac, the animals perished still more rapidly. He then placed under the intlnence of electricity some of the animals covered with plates of tin, and found tbat, so long as they remained connected with the electrical current, thcir vigour appeared to be restored, but that, whenever it was arrested thcy appeared ready to perish.

The object of these expcriments was to ascertain what would be the likely effect of such coverings in certain diseased states of the human frame, and especially in nervous or neuralgic affections, and in rlicumatism. He reasoned, that, if metallic coverings deprived animals of life by producing rapid sinking of the vital powers, the same metallic platcs applied to the human boly would curc or remove those diseases whicl seemed to depend on an excess of organic lifc. On putting lis plan to the test of practicc, he was so fortonate as to find that it removed some nervous, and a few acutc and chronic rheumatic affections.

This plan of treatment was of no avail in any case where the disease was dependent on or connected with organic lesions, or attended wilh fever, or swelling of the part, or with general weakness; on the contrary, in all these cases the metallic plates augmented the disorder.-Edinburgh Med. and Surg. Journ. Jan. 1842, from Cumples Irendus, 20th Sept. 1841.

4. Abscrice of the Uterus, Vaginc, \&c.--Several cases of this description have recently been mentioned in this Journal. (See rol. xxvi, p. 39, 185; rol. i, new serics, p. 348, 493,494; vol. ii, p. 270; and in the last number, at p. 199.) Wre add to these the following:

1. By Dr. R. Borp, (Mredica-Chirurgical Transactions, vol. xxiv.)-A female, aged 72 , died of chronic disease of the brain and lungs. On dissection, the right ovary was found natural, and a round ligament connected to it was lost in the cellular tissue bchind the neck of the bladder. The sitnotion of the left orary was occupicd by a fibrous tumour, of an irregular, globular shape, connected by a round ligament, smaller than that on the right side, but which took a similar course to the bladder. The Fallopian tubes were not present. There was no vestige of a uterus. The external parts of generation presentcd no unusual appearance; but an aperture, about half an inch deep, beneath the orifice of the vagina, was all that existed of tbe vagina. The breasts were well dereloped ior so old a person.

The only information obtained concerning this individual was, that she had been married, but did not live on amicable terms with her husband.

2. By Dr. Wein, of Kassel, (Brit. and For. Med. Rev. October, 1841, from Casper's Wochenechrift.) - The patient was a small, weakly woman, who died at the age of 5. At puberty, her breasts did not enlarge, nor did she then or ever after menstruate, though, at almost regular monthly periods, she had pains in the limbs and other parts of the body. Thronghout life, sbe enjoyed moderately good healtli, and suffered from no peculiar symptoms. She died of pnenmonia.

After death, the clitoris was found rery much developed, bot there werc scarcely any traces of nymphx, and bat little hair about the external organs. The ragina was very small, the hymen perfech and the orifice of the urethra large. The form of the uterus was preserred in the amangement of the peritoneum, but very little of its substance was found in what corresponded. to its 
body, cornua, and only a little more in its cervix. The left ovary resembled only an elongated, flattened eyst, full of fluid; the riglit ovary was in nearly the same state. but appeared connected, by a little tubercle, with the rim of the pelvis. The Fallopian tubes were of about the naturnl length, hut their size was small and proportioned to that of the uterus and ovaries; their abdominal orifices were small, and surrounded by a few imperfect fimbrix. The orifiec of the uterus was flaccid, the cervical part of the eavity was widc, and was continued through the body into two separate cornua.

5. On the Slinging Organs of the Medurx.-The severe effects produced by these animals are generally notieed in all extended works on poisons. Dr. WAGsER, of Gottingen, rcmarks, that it has not yet been ascertained whether the stinging or burning power of these is to he ascribed to a corrosive liquid or to a meehanieal injury. He imagrines that his examinations, made at Nice and Villafranca in 1839 , will aid in deeiding the queslion.

The origin of the stinging is to be rcferrcd to the extcrnal surface of the shin. This has a beautiful, brownish, violet and reddish colour in vartous parts; and when separated, which is exsily done, there appears the homogeneous, jelly-like substanee, which constitutes the real body of the aninal. Whero the red spots oceur, we find, afler the shin is detached, round elevations or inequalitics like warts.

Bctreen the red grains of pigment are to be ohserred round balls or bubules, out of which, frequently, by the aid of a powerful marnifying power, (for this whole ormanization can only be recognized by the mieroscope, fine threads arc seen to project. These threads, spirally rolled up, often come out of themsclves, but al ways do so on the application of a slight pressurc. The balls or capsules, which contain these threads, are very loosely attached and easily fall, and are rubbed off along with the slime when the medusa loses its skin; they are found in quantity, as are also the threads themselves in what is termed the stinging slime of the meduse, as is easily ascertained when these animals are kept in ressels.

The slightest touch of a medusz canses a perceptible burning sensation, and this is more or less severe, according to the vigour of the animals. They only sting from parts of their bodies where the epidermis is preserved. Dr. Wagner never experienced the sensation when he came in contact with portions in wilich the epidernis had been removed. In his case, a burning sensation was fclt in from a few seconds to a minutc after contact; after five minntes, a slight red. ness appeared in his case, and then a simple, lentil-slaped eleration; but, more frequently, three or four near one another. "Thc appearance sometimes resembles nettle-rash. The pain gencrally soon ceases, but it lasted half a day will one of the party, Dr. IIill, and, afier cight days, a redness was still perceptible.

The internal substance of the body (jelly) never stings, nor does any part, where the pigment spots, the capsules, and the hairs are wanting.

Dr. Wagner thinks it probable that the stinging has a mechanical and chemieal origin, and that the parts abovc described are poison-organs.-Edin. Acw Philosophical Journ. Jan. 18.12.

\section{Materia MEDICA AND PHaRMaCy.}

6. Isinglass Plaster.-Mr. Listos has for many sears bcen in the havit of using, afier operations and for otlier surgical purposes, a plaster, consisting of oiled silk covercd with a coating of isinglass.

The following is the method of preparing it:-Moisten an ounce of isinglass with two ounees of water, and allow it to stand for an hour or two intil quite soft; then add three ounces and a half of rectified spirit, previously nixcd with one ounce and a half of water. Plunge the vcssel in a sauccpan of boiling watcr, and thc solution will be complete in a few minutes. 